\title{
Effect of Organic and Inorganic Sources of Fertilizer on Corm Yield and Nutrient Uptake of Gladiolus
}

\author{
Sunita Dhakar $^{1 *}$, K. Swaroop ${ }^{1}$, Kanwar P. Singh ${ }^{1}$, V.K. Sharma ${ }^{2}$, \\ Naveen Singh $^{3}$ and Surender Singh ${ }^{4}$ \\ ${ }^{1}$ Division of Floriculture and Landscaping, ${ }^{2}$ Division of Soil Science and Agricultural \\ Chemistry, ${ }^{3}$ Division of Genetics, ${ }^{4}$ Division of Microbiology, \\ ICAR-IARI, New Delhi- 110012, India \\ *Corresponding author
}

\section{A B S T R A C T}

\section{Keywords}

Gladiolus, Azospirillum, PSB, FYM,

Vermicompost, Nitrogen, Phosphorus, Potash

Article Info

Accepted:

20 January 2019

Available Online:

10 February 2019
An experiment was conducted at the Research Farm of the Division of Floriculture and Landscaping, ICAR-Indian Agricultural Research Institute, New Delhi during Rabi season of 2016-17 to study the effect of integrated nutrient management on corm yield and nutrient uptake of gladiolus cv. Pusa Red Valentine and Pusa Jyotsna. The experiment was laid out in split plot design with a total of twelve treatments and replicated three times. Among all treatments, $\mathrm{T}_{11}(75 \% \mathrm{RDF}+\mathrm{FYM} @ 5 \mathrm{t} / \mathrm{ha}+$ Vermicompost @ $5 \mathrm{t} / \mathrm{ha}+$ Azospirillum + PSB) obtained maximum number of corms per plot (134.66), weight of corms per plot $(5.53 \mathrm{~kg})$ and diameter of corm $(5.33 \mathrm{~cm})$ which was closely followed by treatment $\left(\mathrm{T}_{8}\right)$ than compared to control. The uptake of $\mathrm{N}(2.43 \%), \mathrm{P}(0.189 \%)$ and $\mathrm{K}$ $(2.38 \%)$ was significantly higher in treatment $\left(\mathrm{T}_{11}\right)$ followed by treatment $\mathrm{T}_{8}$ as compared to control. The results also indicated that among the varieties Pusa Red Valentine has recorded maximum uptake of $\mathrm{N}(2.21 \%), \mathrm{P}(0.166)$ and $\mathrm{K}(2.18 \%)$ respectively.

\section{Introduction}

Gladiolus is an important cut flower crop commercially grown in many tropical, subtropical and temperate parts of the world. It is popular for its attractive spikes having florets of huge form, dazzling colours varying sizes and long keeping quality. The importance of gladiolus as cut flowers is increasing day by day in domestic as well as international market. It is also ideal both for garden display and floral arrangements for table and interior decoration as well as making high quality bouquet (Lepcha et al., 2007). At present, the productivity and quality of gladiolus in the international market are declining considerably due to climatic aberrations and mismanagement of soil and nutritional factors. The inadequate and imbalanced use of inorganic fertilizers accompanied with the restricted use of organic manures adversely affects the growth and yield of plant. 
The organic manures and bio-fertilizers are very important for plant growth and yield. They help to nourish the crops by making all the nutrients in available form and in adequate proportions as required by the plants. They help to fix atmospheric nitrogen, solubilize and mobilize phosphorus, translocate minor elements like; $\mathrm{Zn}, \mathrm{Cu}, \mathrm{Fe}$ etc. to the plants, produce plant growth promoting hormones, vitamins, aminoacids as well as control soil borne fungal diseases (Wani, 1990). It improves the physico-chemical and biological properties of soil. It will help to maintain the soil health. Fertilizers play vital role in production and productivity of any crop but continuous and imbalanced use of high analysis chemical fertilizers badly influences production potential and soil health. Use of chemical fertilizer in combination with organic manure is essentially required to improve the soil health.

Increase in fertilizer use efficiency must be ensured to achieve sustainable production. Considering the important role of biofertilizers and organic manures with chemical fertilizer increasing the yield of gladiolus, in the present investigation is proposed on "Effect of Organic and Inorganic sources of fertilizer on Corm yield and Nutrient Uptake of gladiolus".

\section{Materials and Methods}

A field experiment was carried out at the experimental farm of the Division of Floriculture and Landscaping, ICAR-Indian Agricultural Research Institute, New Delhi, during Rabi season of 2016-2017. Two cultivars Pusa Red Valentine and Pusa Jyotsana were combined with 12 nutritional treatments using three replicates. There were twelve treatments i.e. $\mathrm{T}_{1}$, (control); $\mathrm{T}_{2}: 75 \%$ RDF; $\mathrm{T}_{3}: 100 \% \quad$ RDF (200:100:100 kg/ha $\mathrm{NPK}) ; \quad \mathrm{T}_{4}$ : $\quad \mathrm{FYM} \quad @ \quad 10 \mathrm{t} / \mathrm{ha} ; \mathrm{T}_{5}$ : Vermicompost @10 t/ha; T $: 100 \%$ RDF +
FYM @ 5 t/ha; $\mathrm{T}_{7}: \quad 100 \%$ RDF + Vermicompost@5 t/ha; $\mathrm{T}_{8}$ : 125\% RDF + Azospirillum + PSB T9: 75\% RDF +FYM @ $10 \mathrm{t} / \mathrm{ha}+$ Azospirillum + PSB; $\mathrm{T}_{10}: 75 \% \mathrm{RDF}$ + Vermicompost @10 t/ha + Azospirillum +PSB; T $11: 75 \% \mathrm{RDF}+\mathrm{FYM} @ 5$ t/ha + Vermicompost @ 5 t/ha + Azospirillum + PSB; T 12 : 50\% RDF +FYM @ 5 t/ha + Vermicompost @ 5 t/ha + liquid NPK. Medium sized corms were planted during third week of October in lines maintaining row and plant spacing of 50 and $10 \mathrm{~cm}$, respectively at a depth of $5 \mathrm{~cm}$. FYM and vermicompost were added at the time of land preparation. While, full doses of phosphorous and potassium and half dose of nitrogen were incorporated into the beds according to the treatment requirements through urea, single super phosphate and muriate of potash. The remaining half dose of nitrogen was applied after 30 days of planting. While, the biofertilizers (Azospirillum, PSB and liquid NPK) were applied once at the time of planting as treatment using corm dip method for half an hour followed by shade drying before planting. Plant analysis of N, P, Kwas done at the end of the experiment in in Soil science laboratory at IARI, New Delhi by following the standard procedures, microKjeldhal for $\mathrm{N}$ estimation, vanadomolybdate for $\mathrm{P}$ and using flame photometer for $\mathrm{K}$ estimation (Tandon, 1998).

\section{Results and Discussion}

\section{Corm yield}

Different combination of organic manure, biofertilizers and inorganic fertilizers had significantly affected corm character of gladiolus (Table 1). Significantly maximum number of corms per plot (134.66), weight of corms per plot $(5.53 \mathrm{~kg})$ and diameter of corm $(5.33 \mathrm{~cm})$ was recorded in the treatment $\mathrm{T}_{11}$ receiving of $75 \% \mathrm{RDF}+\mathrm{FYM} @ 5 \mathrm{t} / \mathrm{ha}+$ Vermicompost@5 t/ha + Azospirillum + 
PSB, followed by $T_{8}$ and $T_{12}$ and the minimum number of corms per plot (95.66), weight of corms per plot $(2.94 \mathrm{~kg})$ and diameter of corm $(4.52 \mathrm{~cm})$ was recorded in control followed by $\mathrm{T}_{4}$. The use of biofertilizers and organic manure increases number of microbes in soil which result into better root proliferation, more uptake of nutrients and water, luxuriant vegetative growth and more photosynthesis and enhanced food accumulation, enhanced capacity for absorption of ions and water from the soil resulting into increase in yield.

Table.1 Effect of integrated nutrient management on corm characters in gladiolus cv. Pusa Red Valentine and Pusa Jyotsna

\begin{tabular}{|c|c|c|c|c|c|c|c|c|c|}
\hline \multirow[t]{2}{*}{ Treatment } & \multicolumn{3}{|c|}{ No. of corm/plot } & \multicolumn{3}{|c|}{ Wt of corm/plot (kg) } & \multicolumn{3}{|c|}{ Diameter of corm (cm) } \\
\hline & $\begin{array}{l}\text { Pusa Red } \\
\text { Valentine }\end{array}$ & $\begin{array}{l}\text { Pusa } \\
\text { Jyotsna }\end{array}$ & Mean & $\begin{array}{l}\text { Pusa Red } \\
\text { Valentine }\end{array}$ & \begin{tabular}{|l} 
Pusa \\
Jyotsna
\end{tabular} & Mean & $\begin{array}{l}\text { Pusa Red } \\
\text { Valentine }\end{array}$ & $\begin{array}{l}\text { Pusa } \\
\text { Jyotsna }\end{array}$ & Mean \\
\hline $\mathbf{T}_{1}$ & 75.33 & 116.00 & 95.66 & 2.21 & 3.67 & 2.94 & 4.62 & 4.42 & 4.52 \\
\hline $\mathbf{T}_{2}$ & 88.66 & 131.00 & 109.83 & 2.95 & 4.74 & 3.84 & 4.93 & 4.87 & 4.90 \\
\hline $\mathbf{T}_{3}$ & 91.00 & 131.66 & 111.33 & 3.46 & 4.88 & 4.17 & 4.99 & 4.92 & 4.96 \\
\hline $\mathbf{T}_{4}$ & 87.33 & 130.00 & 108.66 & 2.44 & 4.33 & 3.39 & 4.84 & 4.78 & 4.81 \\
\hline $\mathbf{T}_{5}$ & 89.66 & 132.66 & 111.16 & 2.63 & 4.43 & 3.53 & 4.88 & 4.86 & 4.87 \\
\hline$T_{6}$ & 96.00 & 136.00 & 116.00 & 3.60 & 4.91 & 4.25 & 5.03 & 4.91 & 4.97 \\
\hline $\mathbf{T}_{7}$ & 100.66 & 141.00 & 120.83 & 3.61 & 4.93 & 4.27 & 5.06 & 4.93 & 4.99 \\
\hline $\mathbf{T}_{8}$ & 107.66 & 152.66 & 130.16 & 4.00 & 6.00 & 5.00 & 5.25 & 5.11 & 5.18 \\
\hline $\mathbf{T}_{9}$ & 100.66 & 143.00 & 121.83 & 3.68 & 4.98 & 4.33 & 5.00 & 5.05 & 5.02 \\
\hline$T_{10}$ & 107.00 & 155.00 & 131.00 & 3.93 & 5.00 & 4.47 & 5.18 & 5.08 & 5.08 \\
\hline $\mathbf{T}_{11}$ & 111.00 & 158.33 & 134.66 & 5.00 & 6.06 & 5.53 & 5.41 & 5.24 & 5.33 \\
\hline$T_{12}$ & 104.66 & 152.33 & 128.50 & 3.96 & 5.24 & 4.60 & 5.20 & 5.05 & 5.13 \\
\hline Mean & 96.63 & 139.97 & & 3.46 & 4.93 & & 5.03 & 4.93 & \\
\hline $\begin{array}{l}\mathrm{C} D \text { at } 5 \%, \\
\text { For varieties }\end{array}$ & & 2.67 & & & 0.40 & & & 0.06 & \\
\hline $\begin{array}{c}\text { C D at 5\%, } \\
\text { For } \\
\text { Treatment }\end{array}$ & & 6.74 & & & 1.03 & & & 0.30 & \\
\hline $\begin{array}{c}\text { C D at } 5 \%, \\
\text { For } \\
\text { interaction }\end{array}$ & & NS & & & NS & & & NS & \\
\hline
\end{tabular}


Table.2 Effect of integrated nutrient management on uptake of nitrogen, phosphorus and potassium (\%) in gladiolus cv. Pusa Red Valentine and Pusa Jyotsna

\begin{tabular}{|c|c|c|c|c|c|c|c|c|c|}
\hline \multirow[t]{2}{*}{ Treatment } & \multicolumn{3}{|c|}{$\mathbf{N}$} & \multicolumn{3}{|c|}{$\mathbf{P}$} & \multicolumn{3}{|c|}{ K } \\
\hline & $\begin{array}{l}\text { Pusa Red } \\
\text { Valentine }\end{array}$ & $\begin{array}{l}\text { Pusa } \\
\text { Jyotsna }\end{array}$ & Mean & $\begin{array}{l}\text { Pusa Red } \\
\text { Valentine }\end{array}$ & $\begin{array}{l}\text { Pusa } \\
\text { Jyotsna }\end{array}$ & Mean & $\begin{array}{l}\text { Pusa Red } \\
\text { Valentine }\end{array}$ & $\begin{array}{l}\text { Pusa } \\
\text { Jyotsna }\end{array}$ & Mean \\
\hline $\mathbf{T}_{1}$ & 1.60 & 1.52 & 1.56 & 0.121 & 0.104 & 0.113 & 1.78 & 1.53 & 1.65 \\
\hline $\mathbf{T}_{2}$ & 2.12 & 2.10 & 2.11 & 0.146 & 0.144 & 0.145 & 2.10 & 2.09 & 2.10 \\
\hline$T_{3}$ & 2.15 & 2.14 & 2.14 & 0.202 & 0.124 & 0.163 & 2.20 & 2.14 & 2.17 \\
\hline $\mathbf{T}_{4}$ & 1.88 & 1.86 & 1.87 & 0.123 & 0.113 & 0.118 & 1.88 & 1.82 & 1.85 \\
\hline $\mathbf{T}_{5}$ & 2.04 & 2.00 & 2.02 & 0.135 & 0.120 & 0.128 & 2.01 & 1.92 & 1.96 \\
\hline$T_{6}$ & 2.27 & 2.16 & 2.21 & 0.163 & 0.145 & 0.154 & 2.27 & 2.17 & 2.22 \\
\hline $\mathbf{T}_{7}$ & 2.33 & 2.21 & 2.27 & 0.172 & 0.166 & 0.169 & 2.32 & 2.27 & 2.30 \\
\hline$T_{8}$ & 2.47 & 2.36 & 2.41 & 0.188 & 0.180 & 0.184 & 2.38 & 2.35 & 2.36 \\
\hline $\mathbf{T}_{9}$ & 2.36 & 2.23 & 2.29 & 0.172 & 0.165 & 0.169 & 2.26 & 2.20 & 2.23 \\
\hline$T_{10}$ & 2.40 & 2.27 & 2.34 & 0.177 & 0.168 & 0.173 & 2.29 & 2.26 & 2.28 \\
\hline$T_{11}$ & 2.48 & 2.38 & 2.43 & 0.214 & 0.189 & 0.202 & 2.40 & 2.36 & 2.38 \\
\hline$T_{12}$ & 2.43 & 2.29 & 2.36 & 0.183 & 0.168 & 0.176 & 2.32 & 2.30 & 2.31 \\
\hline Mean & 2.21 & 2.13 & & 0.166 & 0.148 & & 2.18 & 2.12 & \\
\hline $\begin{array}{c}\text { C D at } 5 \%, \\
\text { For } \\
\text { varieties }\end{array}$ & \multicolumn{3}{|c|}{ NS } & \multicolumn{3}{|c|}{ NS } & \multicolumn{3}{|c|}{0.04} \\
\hline $\begin{array}{c}\mathrm{C} \text { D at } 5 \%, \\
\text { For } \\
\text { Treatment }\end{array}$ & \multicolumn{3}{|c|}{0.38} & \multicolumn{3}{|c|}{0.003} & \multicolumn{3}{|c|}{0.31} \\
\hline $\begin{array}{l}\text { C D at } 5 \%, \\
\text { For } \\
\text { interaction }\end{array}$ & \multicolumn{3}{|c|}{ NS } & \multicolumn{3}{|c|}{0.005} & \multicolumn{3}{|c|}{ NS } \\
\hline
\end{tabular}

Kumar et al., (2011) also reported that maximum average corm weight $(36.0 \mathrm{~g})$, number of corms per plant (2.3), number of cormels per plant (25.6) and 100-cormel weight $(24.5 \mathrm{~g})$ was found maximum with the treatment i.e. $(\mathrm{CBD}+$ vermicompost 5 tonnes/ha). In an investigation conducted by
Madinat-ul-Nisa et al., (2016) reported the response of integrative nutrient application in gladiolus cv. Priscilla and found significant differences amongst all the treatments. The above results are in conformity with the finding of Sathyanarayana et al., (2017), Godse et al., (2006) in gladiolus. From Table 
1, it was revealed that among the varieties, number of corms per plot (139.97) and weight of corms per plot $(4.93 \mathrm{~kg}$ ) was recorded significantly maximum in Pusa Jyotsnain comparison to Pusa Red Valentine. While, diameter of corm $(5.03 \mathrm{~cm})$ was recorded significantly maximum in Pusa Red Valentine in comparison to Pusa Jyotsna. This might be due to the difference varietal character of the two cultivars.

\section{$N, P$ and $K$ contents in plant at harvest}

The data presented in Table 2 clearly indicate that maximum uptake of $\mathrm{N}(2.43 \%)$, phosphorus $(0.202 \%)$ and potassium $(2.38 \%)$ was recorded in the treatment $\mathrm{T}_{11}$ receiving of 75\% RDF + FYM @ 5 t/ha + Vermicompost @ 5 t/ha + Azospirillum + PSB, followed by $\mathrm{T}_{8}$. The minimum uptake of nitrogen, phosphorus and potassium was recorded in control followed by $\mathrm{T}_{4}$ (FYM @ 10 t/ha). Highest uptake of nutrients in $\mathrm{T}_{11}$ might be due to favorable soil physical properties and solubilizing effect of native soil nutrients due to organic acids produced during decomposition of vermicompost and solubilizing effect of microorganisms. These results are in accordance with Ali et al., (2013) in gladiolus, Sathyanarayana et al., (2017) in gladiolus, Chandrikapure et al., (1999) in marigold, Chaitra and Patil (2007) in China aster, Deshmukh et al., (2008) in gaillardia and Angadi (2014) in chrysanthemum.

Further, the results in Table 2 revealed that among the varieties, uptake of $\mathrm{N}(2.21 \%)$, phosphorus $(0.166 \%)$ and potassium $(2.18 \%)$ was recorded maximum in Pusa Red Valentine as compared to Jyotsna with uptake of $\mathrm{N}(2.13 \%)$, phosphorus $(0.148 \%)$ and potassium $(2.12 \%$, respectively). This might be due to the difference in nutrient uptake capacity of the two cultivars.

\section{References}

Ali, A., Mehmood, T., Hussain, R., Bashir, A., Raza, S., Najam-ud-Din and Ahmad, A. 2013. Investigation of biofertilizers influence on vegetative growth, flower quality, bulb yield and nutrient uptake in gladiolus (Gladiolus grandiflorus L.). International Journal of Plant, Animal and Environmental Sciences, 4(1): 94-99.

Sathyanarayana, E., Patil, S., Chawla, S.L. and Patel, D.K. 2017. Influence of Integrated Nutrient Management on Gladiolus (Gladiolus grandiflorus L.) cv. American Beauty. Int. J. Curr. Microbiol. App. Sci, 6(8): 379-386.

Wani S P. 1990. Inoculation with associated nitrogen fixing bacteria and role in cereal grain production. Indian Journal of Mycrobiology,30: 363-93.

Angadi, A. P. 2014. Effect of integrated nutrient management on yield, economics and nutrient uptake of garland chrysanthemum (Chrysanthemum coronarium L.). The Asian Journal of Horticulture, 9(1): 132-135.

Chandrikapure, K.R., Sadawarte, D.M., Panchabh and Shelke, B.D. 1999. Effect of bioinoculants and graded doses of nitrogen on growth and flower yield of marigold (Tagetes erecta L.). Orissa J.Hort., 27(2): 3134.

Chaitra, R. and Patil, V. S. 2007.Integrated nutrient management studies in China aster (Callistephus chinensis Nees) cv. KAMINI. Karnataka J. Agric. Sci., 20(3): 689-690.

Deshmukh, P.G., Khiratkar, S.D., Badge, S.A. and Bhongle, S.A. 2008. Effect of bioinoculants with graded doses of NPK on growth and yield of gaillardia. $J$. Soils \& Crops, 18(1): 212-216. 
Godse, S.B., Golliwar, V.J., Neha, C. Bramhankar, K.S. and Kore, M.S. 2006. Effect of organic manures and biofertilizers with reduced doses of inorganic fertilizers on growth, yield and quality of gladiolus. Journal of Soils and Crops, 16(2): 445-449.

Tandon, H.L.S. 1998. Methods of analysis of soils, plants, water and fertilizers. Fert. Dev. Consultation Org., 31: 9-16.

Kumar, R., Kumar, R. and Kumar, P. 2011. Effect of integrated use of chemical fertilizers, bio-fertilizers and biostimulants in gladiolus (Gladiolus grandiflorus L.) cv. Sancerre. Progressive Horticulture, 43(1): 149152.

Madinat-ul-Nisa., K.M Malik and Z.A. Rather. 2016. Effect of biofertilizers on growth, flowering and corm yield in Gladiolus (Tourn.) L. cv. Priscilla. GreenFarming, 7(5): 1256-1259.

Lepcha, B., M.C. Nautiyal and V.K. Rao. 2007. Variability studies in gladiolus under mid hill conditions of Uttarakhand. Journal of Ornamental Horticulture, 10(3): 169-172.

\section{How to cite this article:}

Sunita Dhakar, K. Swaroop, Kanwar P. Singh, V.K. Sharma, Naveen Singh and Surender Singh. 2019. Effect of Organic and Inorganic Sources of Fertilizer on Corm Yield and Nutrient Uptake of Gladiolus. Int.J.Curr.Microbiol.App.Sci. 8(02): 2628-2633. doi: https://doi.org/10.20546/ijcmas.2019.802.307 